\title{
Correlation between Competition Law Cases and Corruption(Case Study: Indonesia)
}

\author{
Ningrum Natasya Sirait \\ Faculty of Law \\ Universitas Sumatera Utara \\ ningrum.sirait@gmail.com
}

\author{
Mahmul Siregar \\ Faculty of Law \\ Universitas Sumatera Utara \\ Mahmuls@yahoo.co.id
}

\begin{abstract}
ASEAN member states enacted competition law in the legal system. The goals of competition law are consumer welfare, fair competition including access to market. Competition Law regulates prohibited agreements, conducts and abuse of dominance. Bid rigging (collusive tendering) is one of the prohibited agreements in Competition Law. This violation is found in collusion between government officials and companies in public procurements using state budget which aim to provide public facilities. Bid rigging has correlation with corruption. The interface between the laws can cause complications for law enforcement in terms of burden of proof, prosecutorial authority and court's jurisdiction. Indonesia experiences difficulties in facing the cross-section between competition law and corruption cases. In 1999 Indonesia enacted Law Number 5 of 1999 on Prohibited of Monopoly and Unfair Business Practices. Most cases decided by the Commission for the Supervision of Business Competition (Komisi Pengawas Persaingan Usaha/KPPU) are violations of Article 22 Law Number .5 of 1999 on Bid Rigging or Collusive Tendering on public procurement. Almost all bidrigging cases end with corruption trial. Jurisdiction of corruption case is upheld by Corruption Eradication Commission (Komisi Pemberantasan Korupsi/KPK) together with the police and prosecutors. None of these institutions conducts joint investigation. Coordination is seemingly a difficult task to execute among law enforcers in Indonesia. Therefore, harmonization is the key word to achieve judicial efficiency, consumer welfare and assurance of law enforcement.
\end{abstract}

Keywords- corruption; competition law, consumer welfare.

\section{INTRODUCTION}

The goals and ideals of the Indonesian state are contained in the Preamble of the 1945 Constitution, namely: 1) protecting the whole Indonesian people and their entire native land; 2) promoting public welfare; 3) educating the intellectual life of the people; and 4) establishing a world order based on freedom, eternal peace and social justice. The objectives are then described in the national development planning system realized in the long-term (20 years) plan, medium-term (5 years) plan and yearly plan. Nevertheless, to achieve those goals is not easy because the territory of the country of Indonesia reaches 5,193,250 square kilometers, and $37 \%(1,921,579$ square kilometers) of which is land area composed of 17,504 islands, either inhabited or not, with the population of 261,8 million people in 2016. The large total area and population make Indonesia as the largest archipelagic country and the fourth largest country in the world in terms of its population; however, such large population will be a challenge because the Indonesian expansive population pyramid mostly composed of young age cohort becomes a demographic bonus of labor in the range of 2020-2030 [1].

Indonesia was considered one of the promising countries in Southeast Asia and viewed as possessing a promising economic future as well as being an attractive market for other producer countries. The Gross Domestic Product (GDP) of Indonesia was worth 932.26 billion US dollars in 2016. The GDP value of Indonesia represents 1.50 percent of the world economy. The Indonesia's GDP per capita has steadily risen, from $\$ 857$ in the year 2000 to $\$ 3,603$ in 2016 [2]. Indonesia is the world's 10th largest economy in terms of purchasing power parity, and the only of ASEAN member country as a member of the G-20 which jointly control $75 \%$ of the world trade [3]. Global economic growth is expected to reach $3.5 \%$ in 2017 as investment, manufacturing, trade and commodity prices are improving. The Indonesia's economy in the first quarter of 2017 grew by $5.0 \%$ (YoY), slightly higher than in the fourth quarter of 2016 which grew by $4.9 \%$ (YoY). The growth is influenced by the improvement in global economic conditions although the growth is not evenly distributed. From the domestic side, the performance of economic growth was boosted by the improvement of goods exports that grew significantly by $8 \%$ (YoY) and of services exports that grew by $7.3 \%$ (YoY) and the maintained domestic demands [1].

A supportive global environment together with a strong domestic fundamental condition has made the Indonesia's economy entering 2017 on a strong footing. Fiscal management and credibility have improved, as proved by the improvement of the credit rating of Standard and Poor 
(S\&P) [4]. Nevertheless, corruption problems are still obviously twisted. Various surveys show that Indonesia is still in a group of countries with high levels of corruption. From some aspects assessed in rating the ease of investment in Indonesia, corruption remains the highest aspect of the obstacles. The People's Representative Assembly (DPR) and public services are the country's most corrupt institutions[5]. Recently, the most common form of corruption cases is bribery related to the procurement of goods and services which attracts the attention of the public because of its enormous value, tending to be well structured and planned, and involving many government officials or leaders of institutions/parties, such as a tender for the construction of power plant in Paiton involving government officials, the construction of a sports complex in Hambalang, Bogor, involving political party leaders, members of the DPR and the Minister of Youth and Sports, and the procurement of electronic ID card or e-KTP (the most recent corruption case) allegedly involving the Leader of DPR, one of the Governors and the Minister. The previous e-KTP case has been terminated by the Commission for the Supervision of Business Competition (KPPU) because, based on business competition law, there has been a tender conspiracy during the procurement process.

Procurement of goods and or service is the activity to obtain Goods/Services by Ministry/Institution/Regional Device Work Unit/other Institutions whose process begins from the needs planning until the completion of all activities to obtain Goods/Services [6]. Efficient, open and competitive procurement of Government Goods/Services is essential for the availability of affordable and qualified goods/services, thereby impacting on the improvement of public services. Improving the quality of public services through good and clean governance needs to be supported by effective, efficient, transparent and accountable financial management. To improve the efficiency and effectiveness of the use of state finances spent through the Procurement of Government Goods/Services, it is necessary to create open, transparent, accountable and fair competition principles in the Procurement of Government Goods/Services funded by State Government Budget (APBN)/Local Government Budget (APBD). Therefore, affordable and qualified goods/services which are accountable both in terms of their physical and financial benefits can be obtained for the smooth task of the government and community services.

Public procurement in Indonesia has traditionally been conducted based on presidential decrees (Keppres or Perpres) that were revised from time to time in line with the emphasis of government policy of that time. It was started with Keppres Number 1 of 2000 and has been updated and modified several times to improve the public procurement system. The Perpres have always had multiple objectives in accordance with the emphasis of government policy of that time, for example efficient use of the state funds, promotion of domestic product and services, equity and social justice, and later the fair business competition. In order to tackle fraud in procurement, Indonesian government concernson governing public procurement process which emphasizes on transparency and accountability. Indonesia has an online procurement system namely e-procurement, designed to prevent collusion and corruption in its process. Eprocurement covers electronically bidding process which provides real-time information for the bidders to check their status, approval, or rejection reason. E-procurement system offers a clean procurement process which closes an opportunity to collusion and corruption practices[7].

\section{METHODOLOGY}

This paper will present the existing condition of corruption cases and its relation to bid rigging in competition cases. It will measure the correlation between corruption and bid-rigging especially in using the state budget. Since Competition Law is relatively new in Indonesia and involved economic analysis, the application of empirical method is essential. Hence the study involved data collection from The Indonesian Competition Commission (KPPU) office and Eradication of Corruption Commission (KPK). The data collection supported by data analysis to find out the correlation including the key to resolve the problems [8].

\section{THE REVIEW}

\section{A. Regulations for Procurement in Indonesia}

As regulated by Presidential Regulation Number 54 of 2010 [6], there are 3 types of e-procurement in Indonesia: $e$ tendering, e-catalog, and e-purchasing. E-tendering is a process to select suppliers, and all of the suppliers have a chance to offer their goods and services online. E-catalog is an electronic information system which contains information about the product in detail. E-purchasing is a process to purchase goods and services through e-catalog system. In 2008, only 33 packages of government goods and services procurement worth IDR52,500 billion were offered through e-procurement. However, eight years later, in 2016, the number of government goods and services procurements increased significantly by 147,555 packages with value reaching IDR398,995,119 billion(report-lpse.lkpp.go.id). 


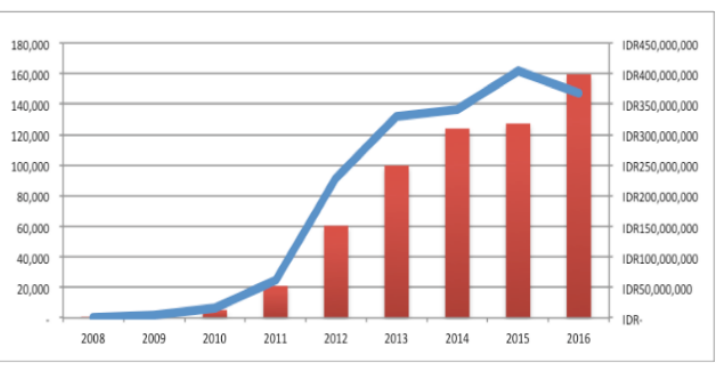

FIGURE 1 Graph of Movement of Total Package of Goods/Services Procurement and Its Value (2008-2016)

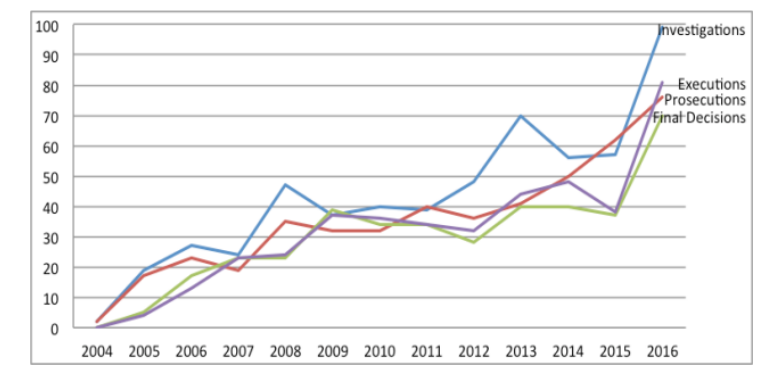

FIGURE 2 Graph of Handling Investigations, Prosecutions, Final Decisions and Executions

The large number of procurement of goods and services is correlated with corruption crimes, especially bribery, gratification, and conflicts of interest in procurement that harms the state finance and economy. The calculation of state losses in Indonesia is conducted by the Supreme Audit Agency (BPK) and the Finance and Development Supervisory Agency (BPKP). The Corruption Eradication Commission(KPK)records that the number of corruption cases in the procurement of goods and services is fewer than in bribery cases, but bribery cases also occur in the procurement of goods and services.Besides, the value of corruption in the procurement of goods and services reaches $75 \%$ of the total value of state financial losses. From 2004 to 2016, the details of corruption cases handled by KPK include investigation on 565 cases, prosecution on 465 cases, final decision on 390 cases, and execution on 414 cases. And the details of the total corruption cases handled from 2004 to 2016 include inspection on 874 cases, investigation on 594 cases, prosecution on 489 cases, in force (in Kracht) on 406 cases, and execution on 434 cases [9].

In addition to corruption cases in the procurement of goods and services, corruption is also closely related to business competition law as regulated in Article 22 of Law Number 5 of 1999 on Prohibition of Monopolistic Practices and Unfair Business Competition whose supervision and law enforcement are conducted by the KPPU. One of the articles in Law Number 5 of 1999 regulates a procurement of goods and services which mentions the prohibition of tender conspiracy. In handling hundreds of cases of the tender conspiracy, it is commonly found that the conspiracy does not only involve the business actors but it also involves the tender committees, aimed at winning one of the participants, the conspiracy even continues to fix the order of winning a procurement of goods/services. For that reason, the business actors bribe the tender committee.

From the data recorded by KPK, the amount of state financial losses from the procurement of goods/services handled by KPK is almost IDR 1 trillion. A survey conducted by Indonesia Procurement Watch also shows that $+/-93 \%$ of entrepreneurs bribe to win project tenders (KPK, 2014). The same data are revealed by KPPU mentioning that during the period of $2006-2012,56 \%$ or 97 cases out of 173 cases that have been decided are related to the conspiracy of procurement tender of goods and services. The total project value of these 97 tender cases is IDR 12.35 trillion, which is a combination of private, state-owned enterprises, APBN and APBD projects. From such total value, a conspiracy of IDR 8.6 trillion has been proved [10].

Based on the Inspection Result of Second Semester of 2014 related to the procurement of goods and services, BPK reported the state loss of IDR 43.62 billion at 17 Ministries or State Agencies $(\mathrm{K} / \mathrm{L})$ due to the lack of work volume, and the potential state loss of IDR 4.11 billion due to overpayment in procurement of goods and services at $7 \mathrm{~K} / \mathrm{L}$. In addition, there has been a waste of state finance of IDR 40.19 billion at $10 \mathrm{~K} / \mathrm{L}$ and ineffectiveness of IDR 69.17 billion at $11 \mathrm{~K} / \mathrm{L}[11]$.

\section{B. The History of Law Enforcement on Corruption Cases in Indonesia}

It is not exactly known when the first corruption practice occurred in Indonesia, but the history recorded that, at least, before the independence of Indonesia, during the kingdom era In 819 , there was a case of tax bubbles involving mangilaladrwya haji (tax officers) from the kingdom who levied taxes from the illiterate people [12]. Within the royal elite, the king preferred to be flattered, honored, valued and disliked for criticism and advice. Criticism and suggestions presented in public are viewed more as a challenge or resistance to his power. Therefore, the culture of power in the archipelago (especially in Java) tended to be authoritarian. In the economic aspect, the king and noble families dominated the economic resources of the society. People were generally left poor, oppressed and submissive, and had to comply with the word, the will or the desire of the ruler. Such close and deceitful culture helped nourishing the culture of corruption in Indonesia. Often abdi dalem (the courtiers) also corrupted in taking a tribute (tax) from the people that would be submitted to the Demang (Headman) which would later be handed over to the Tumenggung (District Head). The Abdi dalem in Ketumenggungan (district or province) also corrupted (though little) the 
treasure that would be handed over to the King or Sultan [13].

The custom of taking a tribute from the common people done by the King of Java was imitated by the Dutch when it dominated the Archipelago $(1800-1942)$. The practice of massive corruption occurred during the colonial period, e.g. the case of misappropriation on the implementation of the "Cultuur Stelsel (CS)" System which literally means Cultural System. Although the main purpose of this system was to cultivate productive crops in the community so that the results would be able to improve the welfare of the people and, at the same time, contributed to the treasury of the Netherlands, the reality was very apprehensive. At that time, farmers could only get 20 percent of their crops and only 20 percent was presumably brought to the Netherlands (Kingdom of the Netherlands). The remaining 60 percent of the archipelago's crops were taken by the local officials of villages and districts [ibid, 13].

The word "corruption" comes from Latin corruptio or corruptus; and the older Latin word corrumpere which means corruption or depravity [14]. In a broader sense, corruption means destructive, twisting, decaying a culture and abusing the trust that has been given by the public [15]. In the Bahasa Indonesia General Dictionary [16], corruption is a destructive act, or misappropriation by means of selfinterest of goods or money under its control, or accepting bribes or embezzlement. Based on these definitions, corrupt behavior includes bribery, extortion, deviation, embezzlement, nepotism, cronyism, misappropriation of public assets for personal interest, and influence on the trade place.

The provisions of corruption crime in Indonesia have actually been regulated since the colonial period and were contained in the Wetboek van StrafrechtvoorNederlandshIndie which have been valid since 1 January 1918, and after the Indonesian independence, Wetboek van StrafrechtvoorNederlandsh-Indie through Law Number 1 of 1946 kept being declared valid but its name was changed to Wetboek van Strafrecht or also called Criminal Code [17]. This Book of Law has actually contained provisions that threaten the crime of people who conduct office delict, especially the delicts (crimes) committed by officials related to corruption. Although the provisions do not clearly mention about corruption, they regulate about bribery, cheating, crime in office, and chartering.

After the Indonesian independence, corruption cases did not disappear. Several cases that had been tried and decided were a gratification on visa arrangement committed by the former Minister of Justice Mr. DjodyGondokusumo in 1957 and a corruption on shroud from Japan by the former
Minister of Religious Affairs K. H. Masykur at the same year [18].

The term corruption was first recorded in the Military Rule Regulation Number PRT/PM/06/1957 issued by the Army Military Ruler and applied to the territory of the Army. The corruption, according to this legislation, was formulated into two kinds: any act committed by anybody either for his own interest, for the interest of others, or for the interest of an agency which directly or indirectly caused financial or economic losses, and any act committed by an officer receiving a salary or wage from an agency receiving assistance from state or regional finances which, by using the opportunity or authority or powers granted to him due to his position, directly or indirectly brought him material/financial gains [19].

The year 1960 became a milestone of legislation to fight against corruption through the issuance of Law Number 24/Prp/Year 1960 on Investigation, Prosecution, and Examination of Corruption Crimes which has been revoked [20] and replaced by Law Number 3 of 1971 [21]. In its development, the state continues updating the law to fight against corruption such as Law Number 11 of 1980 on Bribery [22].

In 1997, like many other countries in Southeast Asia, Indonesia was in the midst of a long and exhausting economic crisis, which worsened along with the world's economic decline, reaching its nadir in 1998. One of the causes of the economic crisis is the presence of centralization of powers, authority and responsibility that does not only have negative impacts on the political field, but also on the economic and monetary fields, such as the practice of state administration which provided more benefits to certain groups and provided opportunities for the growth of corruption, collusion and nepotism. As a back-up effort, reforms in various fields were needed, including legal reforms manifested in the issuance of various laws. The year 1999 was recorded as the year in which Indonesia most frequently issued laws, 69 laws were issued.

Some argued that one of the factors in the economic field, which influenced the crisis, was that Indonesia did not present a clear competition policy. Previously, like many developing and or other non-market countries, competition policy has not been a significant object of public or private sector concern in Indonesia. In an attempt to end the economic crisis, the Government of Indonesia signed a Letter of Intent as a part of an International Monetary Fund (IMF) loan-rescue program in January 1998. Among 50 points outlined in the Letter of Intent, the Government of Indonesia Enacted Law Number 5 of 1999 on Prohibition of Monopolistic Practices and Unfair Business Competition [23]. The law regulates the fair business practices and 
prohibits of monopolistic practices and unfair business competition, by defining business conduct that harms competition through prohibited agreements, prohibited conduct, unfair business practices, and abuse of dominant position. The law also establishes the Commission for the Supervision of Business Competition (KPPU), which is responsible for enforcing the law, and defines the substance of sanctions and penalties for violations of the law. Law Number 5 of 1999 then became a significant step in increasing Indonesia domestic and international competition. In addition, Law Number 8 of 1999 [24] on Consumer Protection was issued which was separate from Law Number 5 of 1999 and was implemented by different agencies as well, namely the National Consumer Protection Agency and for its dispute settlement was handled by the Consumer Dispute Settlement Agency.

Furthermore, in order to rescue and normalize the national life in accordance with the demands of the reform, Law Number 28 of 1999 on Government Executives who are Clean and Free from Corruption, Collusion, and Nepotism was issued [25]. This law applies general principles of good state governance which includes the principle of legal certainty, the principle of orderly state administration, the principle of public interest, the principle of openness, the principle of proportionality, the principle of professionalism, and the principle of accountability. The main objectives of this Law are addressed to State Administrators that include State Officials of the Supreme State Institution, State Officials at State Higher Institutions, Ministers, Governors, Judges, State Officials and/or Other Officials who have strategic functions in relation to the administration of the state in accordance with the provisions of prevailing laws and legislations. In order to achieve its objectives effectively, the Law regulates the establishment of Examining Commission authorized to examine the assets of the state officials before, during and after their terms in office, including requesting information from the former state officials, their family and their cronies, as well as businessmen, by keeping in mind the principle of presumption of innocence and human rights. This Examining Commission became the forerunner to the establishment of the Corruption Eradication Commission (ibid, 25).

Law Number 31 of 1999 on Eradication of Corruption [26], which was later amended by Law Number 20 of 2001 [27], was issued to replace Law Number 3 of 1971 which does no longer correspond to the development of legal needs in the society. The new provisions regulated in this law include: 1) the extension of the state finance definition into all state assets in any form, either separable or inseparable, which incurs rights and obligations to anyone who controls them; 2) the definition of unlawful in the context of corruption crimes can also include disgraceful acts which, according to the sense of community justice, should be prosecuted and punished; 3 ) corporation as the subject of corruption crimes which may be subject to sanctions; 4) special minimum criminal penalties, higher fines penalties, and the threat of capital punishment as the criminal liability; 5) imprisonment for the corruption criminals who cannot pay additional penalties in the form of state compensation money; 6) the extention of Civil Servant definition to, among others, a person receiving wages and salaries from corporations using capital or facilities from the State or the society; 7) investigators, public prosecutor or judges in accordance with the level of case handled are authorized to directly inquire information about the financial condition of the suspect or the defendant to the bank by submitting the matter to the Governor of Bank Indonesia; 8) the joint team coordinated by the Attorney General; 9) limited reverse verification; and 10) the establishment of the Corruption Eradication Commission which will be regulated in a separate law within a period of no more than 2 (two) years since the law is enacted.

In 2002, Law Number 30 of 2002 on Corruption Eradication Commission (KPK) was issued [28], and in 2009, Law Number 46 of 2009 on Corruption Court was issued [29]. The Corruption Court has actually been regulated in Law Number 30 of 2002, but the Decision of the Constitutional Court Number 012-016-019/PUUIV/2006 states that a special court can only be established within one of the general courts established under a separate law.

The state also continues to update other laws related to corruption, such as Law Number 15 of 2002 [30] which has been amended by Law Number 24 of 2003 [31] on Amendment to Law Number 15 of 2002 on Money Laundering Crimes, Law Number 1 of 2006 [32] on Criminal Assistance for Criminal Matters, Law Number 7 of 2006 [33] on Ratification of the United Nations Convention against Corruption in 2003, Law Number 13 of 2006 [34] on Protection of Witnesses and Victims, and Law Number 8 of 2010 on Prevention and Eradication of Money Laundering Crimes [35].

Based on the provisions of Law Number 31 of 1999 $[19,26]$, the corruption crimes are formulated into 7 forms/types, namely: 1) detrimental to the state finances and economy; 2) bribes; 3 ) embezzlement in office; 4) extortion; 5) cheating; 6) gratification; and 7) a conflict of interest in procurement. The interesting point of this provision is that all these forms can be related to a conflict of interest in procurement.

In 2016, the Police, Attorney and KPK handled 482 corruption cases with 1,101 suspects and state losses of IDR 1,449,000,000,000 including mark-up, embezzlement, abuse of authority and fictitious projects whose value of bribes was worth IDR 31,000,000,000; of that amount, 195 cases were related to the procurement of goods and services. 
Viewed from the number of cases, only about $40 \%$ of the total number of corruptions has been handled, but when viewed from the amount of bribery in the case of procurement of goods and services reaching IDR $23,200,000,000$, it has constituted $75 \%$ of the total value of bribes handled[36].

\section{Major Corruption Cases}

A criminal case will be related to other violations of law. This is in line with the opinion of the Constitutional Court which views that corruption that has harmed the social and economic rights of Indonesian people is an extraordinary crime and a common enemy of Indonesian society and nation as a whole. Corruption has undermined the country's ability to provide good public services and hindered the effective functioning of state administration. It becomes a heavy economic burden because it creates high macroeconomic risks that endanger financial stability, public security, law and order. Moreover, this can undermine the legitimacy and credibility of the state in the eyes of its people. In addition to causing direct losses to the state finances, i.e. the loss of state money to enrich the corruptors themselves or others, corruption cases, especially those related to infrastructure development, either soft or hard, also resulted in losses to the country's economy in the wider scope and in the long-term period, such as the corruption in private electricity procurement in Paiton resulting in today's shortage of electricity supply, the corruption in procurement of the Construction of Training Center and School of Sports in Hambalang affecting the decline in the Indonesia's sport achievement, and the corruption in e-KTP procurement affecting not only on citizens' administrative problems but also on the issues of citizens' constitutional rights to participate in the general election.

The BPKP audit reported a markup and massive conspiracy on the private electricity setup process and on the procurement of private power investment process of Paiton I in Probolinggo since 1993. The report discusses the process of Corruption, Nepotism and Collusion (KKN) practices including the planning, process of obtaining a Principle License, financing, execution, production, distribution, consumption, payment and various privileges obtained by harming the state finance. The preliminary finding was initiated from the markup on capital cost of $48 \%$ of the total project value of IDR 7.015 trillion. Until today, the case has not yet been revealed although it has been reported to all law enforcement officers, police, prosecutors and KPK. Not only does it affect the state material losses, but it also affects the shortage of electricity supply that hampers the national investment and development.
In 2009, the Ministry of Youth and Sports considered that Indonesia needs to have a National Training Center and School of Sport. Therefore, a verification team was formed which then conducted a survey to some places and determined Hambalang area as the location corresponding to the education center construction plan. It turns out, however, that Hambalang is located at the zone of vulnerability of medium-high land movements in accordance with disasterprone maps published by the Center of Volcanology and Geological Hazard Mitigation (PVMBG), the Ministry of Energy and Mineral Resources (ESDM). In accordance with the nature of the rocks, PVMBG suggested not to construct a building on that location because it has high congenital risks for the occurrence of natural disasters in the form of land movement. However, in its process, the Local Government of Bogor and the Head of Land Agency kept issuing the right to use to the Ministry of Youth and Sports. Having obtained the right to use the land, the Ministry of Youth and Sports requested an additional budget of IDR 125 billion to reach the total budget of IDR 1.75 trillion. This request was then investigated by BPK that found the potential state loss of IDR 243.9 billion. In addition, the KPK, with its phone-tapping authority, also successfully recorded the conversation between the perpetrators of corruption, and this case eventually involved the Minister of Youth and Sports and the leader of a political party. The state loss does not include the loss of the people who used to cultivate the land and had to give up their livelihoods and the loss of the society in general because they do not have a National Training Center and Sport School. Furthermore, such corruption practice affects the Indonesia's achievements in sports as Indonesia is currently often left behind in sporting achievements even at the smallest level of competition, such as ASEAN regional sports event.

KPPU has decided that there was a conspiracy in the case of e-KTP procurement tender which did not only involve the bidders, but also the tender committee. This case ended up in the high-cost economy due to the mark-up by the parties involved, of the total project value worth IDR 5.9 trillion, the corrupted funds allegedly reached IDR 2.3 trillion or almost $50 \%$ of the total project value. Mark-up, according to business competition law, is an evidence of tender conspiracy, but the mark-up itself is a part of corruption provision which is not the authority of KPPU, and this mark-up finding is, therefore, forwarded to law enforcement officers, i.e., KPK. The KPK has followed up the findings and has brought the case to court that has started the trial and has adjudicated the case by punishing at least 2 (two) of its bribery perpetrators. Nevertheless, the KPK did not stop the case because several other bribe receivers had not been completely investigated. The KPK has decided the Leader of DPR as the suspect of bribery and 
other allegations as extensively published in the mass media such as a governor and a minister.

\section{Several important issues}

There are several issues developed regarding with the KPK's authority in terms of law enforcement of corruption cases in Indonesia (the authority overlapping and the absence of comprehensive coordination among various institutions authorized to handle corruption cases).

The Corruption Eradication Commission (KPK) was established for law enforcement purpose to eradicate corruption committed conventionally has been proven to encounter various obstacles. Therefore, it needs an extraordinary method of law enforcement through the establishment of a special body which has a wide and independent authority and is free from any power in the effort to eradicate corruption, whose implementation is done optimally, intensively, effectively, professionally and sustainably. However, lawmakers are also aware that the current corruption eradication has been conducted by various institutions such as prosecutors and police and other bodies related to corruption eradication; therefore, the regulation on the authority of the Corruption Eradication Commission in this Law should be carried out cautiously in order to avoid overlapping of authority with other various agencies, this Law even clearly states that KPK does not monopolize the duties and authorities of inspection, investigation and prosecution. The authority of the Corruption Eradication Commission in conducting inspection, investigations and prosecutions of corruption includes corruption cases involving law enforcement officers, state administrators, and other people related to corruption committed by law enforcement officers or state officials; cases gaining attention that is troubling the public; and/or cases concerning state losses of at least IDR $1,000,000,000$.

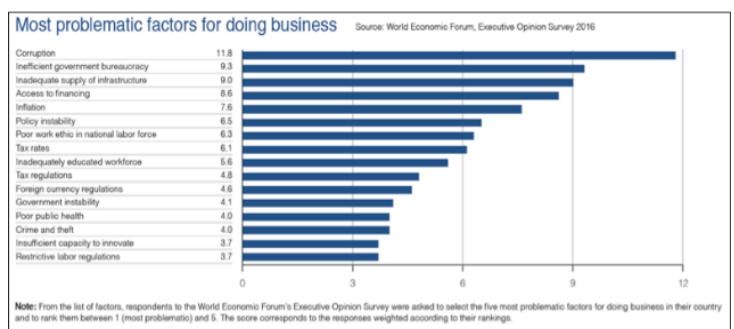

FIGURE 3 Most Problematic Factor for Doing Business in Indonesia (2006)

The Police, Attorney, and Corruption Eradication Commission have the authority to investigate corruption cases did not decrease the number of corruption practices, on the contrary, what happens now is the attraction of interinstitutional authority resulting in the obstruction of law enforcement process, and this condition even worsens by the possibility of having internal conflict among the law enforcement officers caused by corruption perpetrators. This condition can be seen in the Global Competitiveness Report 2016-2017 stating that Indonesia (41 $\left.{ }^{\text {st }}\right)$ drops four places as it is overtaken by a few countries. Despite many reforms to its business environment, its performance remains one of contrasts: the country ranks $10^{\text {th }}$ for market size, $30^{\text {th }}$ in the macroeconomic environment pillar - in spite of the protracted commodity bust -and $31^{\text {st }}$ for innovation. It performs well in terms of financial development $\left(42^{\text {nd }}\right.$, up seven) and effectiveness of anti-monopoly policy at $51^{\text {st }}$ among 138 Countries. And the most problematic factor is Corruption[37].

The case of "Lizard vs. Crocodile" is one of the events that shows to the public the lack of coordination among the law enforcement officers, whereas the KPK was established in the hope that KPK 1) can establish a strong networking and treat the existing institutions as a conducive "counterpartner" so that corruption eradication can be implemented efficiently and effectively; 2) does not monopolize the duties and authorities of inspection, investigation, and prosecution; 3) serves as a trigger and empowerment of existing institutions in corruption eradication (trigger mechanism); and 4) serves to supervise and monitor the existing institutions, and, under certain circumstances, may take over the duties and authorities of inspection, investigation and prosecution (superbody) being carried out by the police and/or prosecutors.

The KPK also quite often calls other law enforcement officers without permission from their institution head, whereas in the law regulating law enforcement officers, it is stipulated that law enforcement officers can only be called after being permitted by their institution head. As a result, in 2017, KPK, the Police and the Attorney General of the Republic of Indonesia agreed on a memorandum of understanding on cooperation in corruption eradication. It contains an agreement that, in the event that one of the parties searches, seizures or enters another party's office, the party should notify the leader of the party being investigated, unless being caught red-handed. And in the event that one of the parties makes a call to the other party's personnel, the party should notify the leader of the party whose personnel is being called.

\section{E. Business Competition in Indonesia}

\section{Background of the Issuance of Law Number 5 of 1999}

The principle of a fair business competition, particularly the prohibition of monopolistic practices, has been contained in Article 37 Paragraph (3) of the 1950 Provisional Constitution of the Republic of Indonesia [38] which reads: "The authority shall prevent, in accordance with rules to be laid down by law, the existence of private monopolistic organizations which are harmful to the national economy in accordance with the regulations 
stipulated by the Law". However, on July 5, 1959, Presidential Decree of the Republic of Indonesia was issued regulating to re-apply the 1945 Constitution which does not specifically regulate business competition in its articles on economy [39]. Article 33 Paragraph (1) of the 1945 Constitution stipulates that "the economy shall be organized as a common endeavor based upon the principle of a family system ." The fourth Amendment of the 1945 Constitution Article 33 Paragraph (4) stipulates that "the national economy shall be organized based on economic democracy with the principles of solidarity, efficiency along with fairness, sustainability, keeping the environment in perspective, self-sufficiency, as well as based on maintaining balanced progress and the unity of the national economy".

In practice, the business opportunities created over the past three decades have, in fact, not made the whole community capable and able to participate in the development within various economic sectors. The development of private business during that period, on the one hand, was distorted. On the other hand, the development of private business is, in fact, largely a manifestation of unfair business competition conditions. The above phenomenon has evolved and is supported by the relationship between decision-makers and business actors, either directly or indirectly, thus further worsening the situation and causing social inequality. The implementation of the national economy less refers to the mandate of Article 33 of the 1945 Constitution and tends to exhibit a very monopolistic style. Democracy in economic sector requires an equal opportunity for every citizen to participate in the process of producing and marketing goods and or services, in a healthy, effective and efficient business climate so as to promote the economic growth and the operation of a reasonable market economy which, therefore, prevents the centralization of economic power to certain business actors. Based on this economic democracy, Law Number 5 of 1999 was issued which was intended to enforce the rule of law and provide equal protection for every business actor in an effort to create a fair business competition.

\section{Substance and Law Enforcement of Law Number 5 of 1999}

Indonesia enacted Law Number 5 of 1999 on Prohibitions of Monopolistic Practice and Unfair Business Competition and the enforcement is provided by the Commission for the Supervision of Business Competition (KPPU). Law Number 5 of 1999 was formulated based on the criteria of economic efficiency and consumer welfare. Law Number 5 of 1999's primary focus is on the prohibition of unfair business practices that may result in monopolistic practices or an unfair business competition. The prohibition of a monopolistic practice is categorized into 3 (three) forms: prohibited agreements, prohibited activities and abuse of dominant positions. Prohibited agreements include oligopoly, pricing, resale price maintenance, territorial division, boycott, cartel, trust, oligopsony, vertical integration, closed agreements and agreements with foreign parties. Prohibited activities include monopoly, monopsony, market control, loss on sale, fraudulent manufacturing costs, tender conspiracy, conspiracy to gain company secrets and conspiracy to hinder competitors. The dominant position includes abuse of dominant position, multiple positions, cross stock ownership and merger, acquisition and takeover. Law Number 5 of 1999 also contains exceptions which include exceptions to intellectual property rights and Small Medium Enterprise (SME) whose limit is set out in a separate law.

Law Number 5 of 1999 also regulates the establishment of Commission for the Supervision of Business Competition (KPPU) which has the duty of supervising and the authority of enforcing business competition law under Law Number 5 of 1999 with procedural law which has also been generally specified in the law. The authority of KPPU to enforce Law Number 5 of 1999 is wide-ranging, starting from receiving reports from the community and conducting research on its own initiatives when finding alleged violations of Law Number 5 of 1999, investigating, prosecuting and up to deciding business competition cases.

\section{Article 22 of Law Number 5 of 1999}

One of the prohibited agreements in Competition Law is in the form of bid-rigging or collusive tendering. This type of violation is mostly found in a collusion between government officials and commercial companies to decide who will win a public procurement contract. Among other facts, public procurements funding mostly used the state budget which aims at providing infrastructures or public facilities. Most of the time, the collusion involved government officials (tender committee) and the bidders or commercial companies.

The definition of conspiracy is a combination or confederacy between two or more persons formed for the purpose of committing, by their joint efforts, some unlawful or criminal acts, or some acts which are innocent in themselves, but becomes unlawful when done concerted action of the conspirators, or for the purpose of using criminal or unlawful means to the commission of an act not in itself unlawful. Meanwhile, a bid-rigging is an agreement between parties over which competitor will win a tender often from government agencies. This agreement may be accomplished by submitting bids, or by the bidders agreeing on a low bidder and then bidding above that firm's intended (and inflated) price. The tendering process is designed to promote fairness and reliability to ensure that the lowest 
price is received. A bid-rigging subverts this competitive process.

Article 22 of Law Number 5 of 1999 which reads: "businesses are prohibited from conspiring with other parties to arrange and determine the winner of a tender thus causing an unfair business competition ," specifically regulates the prohibition of tender conspiracy. The provision in this article which contains the words "... conspiring with other parties ..." and "... causing an unfair business competition" makes this article has 2 (two) uniqueness, namely: 1) using the rule of reason approach, while the best practice in various jurisdictions in other countries uses the illegal per se approach, including hardcore cartel which is handled by criminal law mechanism; and 2) not limited to horizontal conspiracies but also including vertical conspiracies or mixtures between horizontal and vertical conspiracies, while business competition law theory regulates that a tender conspiracy included in a business competition law is a horizontal conspiracy among competitors, when it involves a vertical conspiracy, then it will no longer be the business competition domain. Such vertical conspiracy or a horizontal -vertical conspiracy is the conspiracy that makes the handling of business competition cases in the alleged tender conspiracy in Indonesia very close to the corruption crimes in the procurement of goods and or services.

Articles in law are certainly allowed to be interpreted in order to better understand it, but this interpretation would be severely restricted to prevent excessive interpretation that obscures the intention of the law itself. Interpretation or construing the law (wetsuit leg), according to the law teachings, is actually a supporting tool in giving meaning, purpose or ratios to a law provision because a legal provision cannot provide legal settlement to real-world problems.

Grammatical interpretation and original intent are the most recommended tools. Grammatical interpretation means an interpretation that is based exclusively on the words themselves. It uses words in phrases and sentences to construct meaningful combinations. It is also called a historical-grammatical method. Original intent is the theory of interpretation by which judges attempt to ascertain the meaning of a particular provision of a state or federal constitution by determining how the provision was understood at the time it was drafted and ratified. Indonesian Competition Law memorandum of legislation recorded that the original intent of the lawmakers (parliament and government) wants that conspiracy is not only among the businesses (horizontal collusion) but also among any parties involved in bid-rigging (a horizontal or a horizontal-vertical combine collusion) because throughout its history, in
Indonesia it shows that a tender conspiracy very often involves unscrupulous government officials.

\section{Landmark Cases of Implementing Article 22 of Law Number 5 of 1999}

Bid-rigging cases under the Competition Law in 16 years implementing the Competition Law (2000-2015) recorded that KPPU has had settled 272 decisions and 64\% of which (173 decisions) were bid-rigging cases. And $71 \%$ (123 decisions) of 173 bid-rigging cases involved other parties, i.e. procurement committee and procurement service unit.

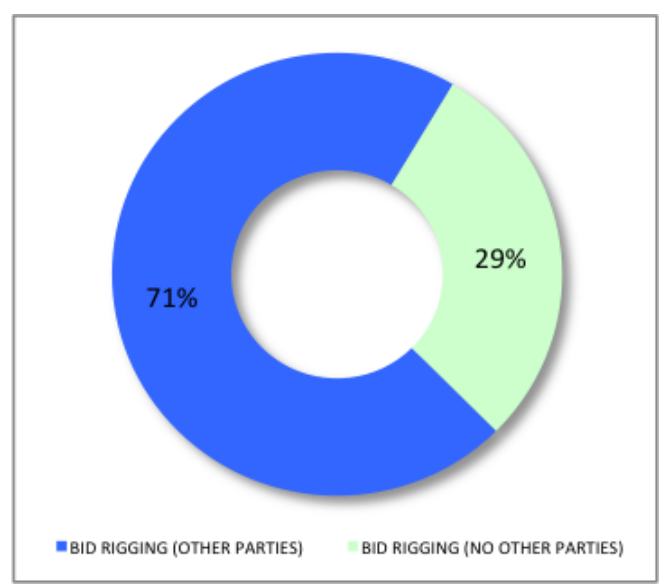

FIGURE 4 Comparison of Number of Tender and Nontender Cases

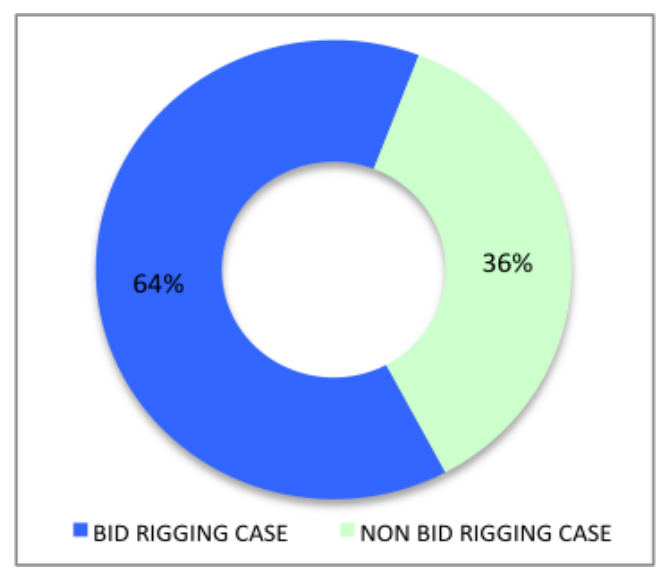

FIGURE 5 Comparison of Tender Cases Involving Other Parties and Not Involving Other Parties

The first case handled by KPPU (Case No. 01/KPPUL/2000)occurred in 2000 with the alleged tender conspiracy among the participants of the procurement of pipe casing and tubing by PT. Caltex Pacific Indonesia in Rumbai, Pekanbaru [40]. The participants were proven to have a meeting and adjust the bid price before submitting the pricing document to the job owner. In 2001, KPPU handled 
the first case of a tender conspiracy involving government officials in the case of Cattle Procurement in Surabaya. In this case(Case No. 07/KPPU-L-I/2001), KPPU found that there was facilitation for the tender committee to travel to Australia by one of the bidders, and as a return, the bidder was admitted as the participant and won the tender, even though the participant did not have the qualification to participate in such tender [41].

In 2002, KPPU handled a tender case (Case No. 03/KPPU-I/2002) of Sale of Shares and Bonds (convertible bonds of PT Holdiko Perkasa and convertible bonds of BPPN) of PT. Indomobil Sukses Internasional, Tbk., which was, at that time, considered controversial because the KPPU was considered to have extended the definition of a tender more than the one stipulated by Law Number 5 of 1999 regulating that a tender is a bid to propose a price to buy a job, to procure goods or to provide Services [42]. This was also the case in which the KPPU, for the first time, stated the existence of state losses reaching hundreds of billions of rupiah due to the tender conspiracy of the participants and the tender committee that regulated the pricing so that the sale price of shares and bonds (convertible bonds of PT Holdiko Perkasa and convertible bonds of BPPN) of PT. Indomobil Sukses Internasional, Tbk., is lower than it should be. In addition, this decision also became the first milestone of KPPU cooperation with the criminal law enforcement officers because, in the consideration of the decision, KPPU stated that "... conspiracy and acts outside the legal norm of propriety in the procedure for a tender process resulted in an unfair business competition required to be followed up by investigators of the Attorney General's Attorney".

In 2004, KPPU handled the case (Case No. 7/KPPUL/2004)of a tender conspiracy of Selling 2 (two) units of Very Large Crude Carrier ("VLCC") Tankers owned by PT. Pertamina (SOE) [43]. This case was debatable since KPPU was considered to be beyond the definition of a business actor by stating that the actors of foreign-owned enterprises violated the competition law in Indonesia because of a tender conspiracy to obtain 2 (two) VLCC units and also extended the tender definition as set forth in the Decision Number 03/KPPU-L/2002 mentioned above. The tender conspiracy occurred when the bidding committee gave privilege to 2 (two) bidders by facilitating the post-bidding and did not give the same opportunity to 2 (two) other bidders. With such facilitation, the potential state loss reached up to five hundreds billion rupiah.

In the same year, Indonesia held a general election for legislators for the umpteenth time, and introduced a new method of inking on the finger as evidence for citizens who have used their political right to vote and to be elected. This ink was used to prevent cheating of citizens in using their right to vote more than once. In the procurement of the ink, there has been a conspiracy in various forms between the tender participants and the tender committee, such as determining the country of origin of the ink, changing the requirements of tender participation so that unqualified business actors could join as participants, and inflating the price so that there was a state loss reaching billions of rupiah. The KPPU's decisions on the case (Case No. 08/KPPU-L/2004) were, in addition to imposing fines sanction, ordering the guilty parties to compensate the state loss and advising the investigating agency to take further action and inspection to the tender Committee [44]. KPK, then, followed up these findings and in 2006, by the Local District Court of Jakarta Pusat, the tender committee was sentenced to prison for 4 (four) years for having been proven to corrupt in the tender of the ink procurement.

In 2012, KPPU handled a case (Case No. 3/KPPUL/2012)of alleged tender conspiracy [45] in the Implementation of National NIK Based Identity Card (Electronic KTP). This case became one of the major cases of KPPU because it was handled by 5 (five) Commissioners (usually one case was handled by 3 (three) Commissioners only). In this case, although it was decided that there was a conspiracy of the tender, the decision was not unanimous, because 2 (two) Commissioners who used their dissenting opinion rights stated that this case could not conclude that there was a tender conspiracy since it had no sufficient and adequate evidence. KPPU's decision stated that the tender conspiracy occurred by the agreement between the tender committee and several participants to pass the candidate who did not meet the classification and restricted the requirements of other business actors, as well as allowed for post bidding. Currently, the e-KTP case is also handled by KPK, and the Indonesian Court for Corruption Crimes (Tipikor) has decided there has been a corruption practice committed by 2 (two) business actors.

Based on some literature, significant relationships between (potential) corruption and competition climate cannot be confirmed yet. Various factors that affect competition conduct may be different from those that affect corruption conduct [46]. Therefore, there is not always a correlation between competition index and corruption index. The relationship between competitiveness and corruption is not easy to comprehensively explain. A slight unparalleled condition may also be perceived when we compare corruption Index and competitiveness indexin Indonesia, and corruption ranking and competition ranking in the past consecutive 10 years $[47,48]$ as follows: 


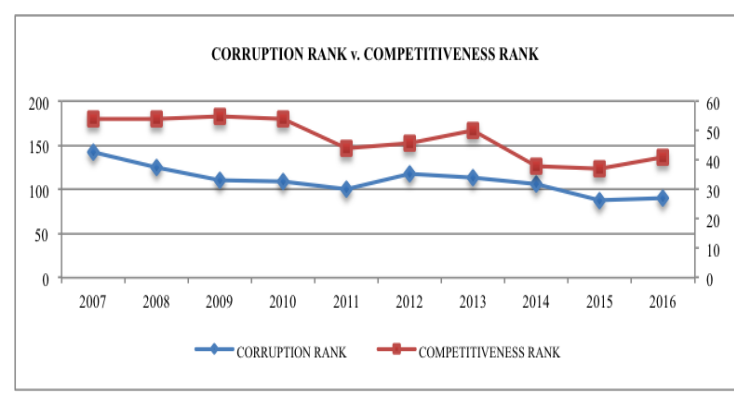

FIGURE 6 Graph of Comparison of CorruptionIndex with Competitiveness Index

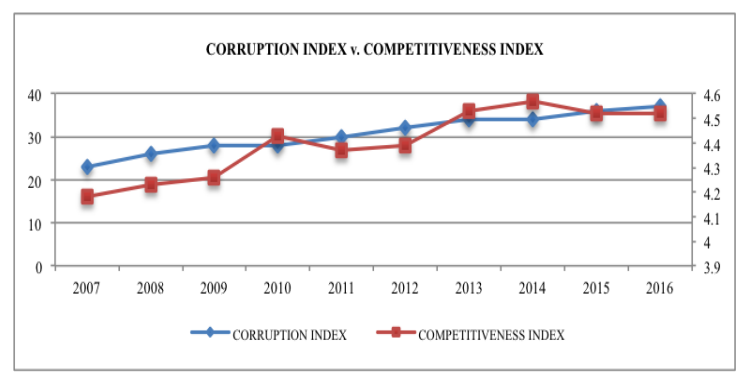

FIGURE 7 Graph of Comparison of Corruption Rank with Competitiveness Rank

In Indonesia, a conspiracy commonly occurred between government officials and commercial companies to determine who would win the public procurement contract. Among other facts, public procurements funding mostly used the state budget which aimed at providing infrastructures or public facilities. Most of the time, the collusion involved government officials (tender committee) and the bidders or commercial companies.

A collusive tendering or bid-rigging has a correlation between the corruption and the competition law. A corruption falls under the section of a criminal law while the competition law regulates behavior of commercial companies when competing in the market. This interface can cause complications for a law enforcement due to conflicts between the competition law and the criminal law. Enforcement or technical procedural may exists in pursuant to burden of proof, prosecutorial authority and the jurisdiction of various courts. The cases handled by the KPK and KPPU also show a different trend graph, as follows:

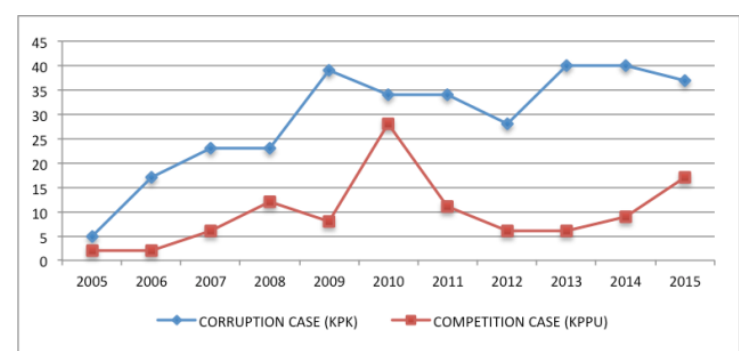

FIGURE 8 Graph of Comparison of Corruption Cases in Procurement of Goods/Services (KPK) with Tender Conspiracy Cases (KPPU)

The graph presented in Figure 8 shows that very few criminal cases being handled by the KPK are also, at the same time, handled by the KPPU and vice versa. The cases should, in fact, be a summation to create effectiveness and efficiency in handling cases of alleged violations of Corruption Law and Business Competition Law.

\section{RESOLUTIONS AND RECOMMENDATIONS}

\section{A. State loss and people's welfare}

Witnessing the large number of cases related to Article 22 on Bid rigging, it is necessary to find out how big the State loss and loss of community welfare. Based on the description of corruption cases, especially in the field of procurement of goods and services as well as a tender conspiracy, it is obviously seen that both KPK and KPPU have a trend of handling cases that continues to increase, but very few cases have interrelations in their handling process; whereas corruption cases in the field of procurement of goods and services always have the dimension of a tender conspiracy and vice versa (the majority of tender conspiracy cases have the dimension of corruption). The cases of corruption handled by the KPK and the cases of tender conspiracy handled by the KPPU generally viewed the actual financial loss of the state, but they have not yet deepened their analysis on the long-term welfare loss, which, in this article, takes the example of the loss of society in the supply of electricity, national sports achievement improvement, and constitutional rights in general elections. Both of the law enforcement officers should look not only from the side of a law enforcement, but also from the side of a sustainable economic development.

Corruption is believed to correlate with state's economy. The correlation could be notified in terms of low investment rate and the slow down economy of the State. Corruption is also triggered the high government expenditure due to the high cost of procurement which at the end will generate state debt increase. While for consumer welfare, high corruption will cause impact on poverty and slow economic growth. On the other hand, it may also affect the job opportunities for the people. Therefore, it is certain that 
corruption may destroy a state and it is undeniable that corruption should be treated as extra ordinary crime.

\section{B. Comprehensive procedural law}

Indonesia has broad experiences in facing the crosssection between the competition law and the corruption cases. Indonesia has enforced its Competition Law (or known as Law Number 5 of 1999 on Prohibition of Monopoly and Unfair Business Practices) since 1999. Most reports and cases decided by the Commission for the Supervision of Business Competition (KPPU) are basically the violations of Article 22 Law Number 5 of 1999 on Bid Rigging or Collusive Tendering on public procurement contracts. The fact shows that almost $90 \%$ of the cases taken and decided by the KPPU were bid-rigging cases. It has been interesting facts that almost all of the cases end in corruption cases. In Indonesia, a corruption case is upheld by Corruption Eradication Commission or Komisi Pemberantasan Korupsi (KPK) including the police and prosecutors.

A large number of incisions are found between corruption cases in the procurement of goods/services and a tender conspiracy, but in practice they look like railroads that go side by side but never meet. This condition will be very easily utilized by corrupt officials to deal with a case with whatever goal it wants to achieve. Therefore, it is necessary to immediately get rid of sectorial ego among law enforcement officers because, in fact, they have the same intention to enforce the law. Breakthroughs need to be made to improve effectiveness in case handling, such as changing the provisions of substantive article so that they become more comprehensive for the current condition, completing the existing procedural law so that it will possibly be implemented effectively and efficiently, and opening opportunities for a cooperation with other law enforcement officers as well as making a memorandum of understanding that serves not only as a symbol of the unity of law enforcement officers but also as the operational basis in the case settlement. All of them have the same vision to achieve the ideals of the nation and state as stated in the constitution.

\section{CONCLUSIONS}

A bid-Rigging in many jurisdictions is handled with an illegal per se approach even some jurisdictions classify it as a hardcore cartel and is handled criminally. Meanwhile, in Indonesia, the approach used is the rule of reason approach. Determining the use of a particular approach is entirely a country's political decision, but a change in the approach used is certainly possible as long as it does have a purpose to make the competition law stronger. Law Number 5 of 1999 is currently in the amendment stage by the Government and the People's Representative Assembly; therefore, now is the right moment to turn Article 22 into an article formulated by using an illegal per se approach. This proposal is based on the theory of tender conspiracy and the practice of its settlement in many countries. KPPU has decided 199 cases of a tender conspiracy and $77 \%$ of which have proven the existence of a tender conspiracy. In addition, in order to suppress the level of tender conspiracy, a stronger legal regulation is required.

The handling of corruption has been mandated by the Corruption Law and KPK Law in which KPK needs to coordinate with other law enforcement officers. As for the handling of corruption in the procurement of goods/services associated with a tender conspiracy, it is necessary to conduct a joint investigation by KPPU, KPK, and other institutions. By conducting a joint investigation, it is expected to gain an efficiency and effectiveness in handling the cases. Consequently, it is necessary to immediately form a task force among agencies considering that the corruption and the tender conspiracy belong to extraordinary crimes.

Currently, KPPU has decided many cases of a tender conspiracy involving procurement officials, but the cases have not yet been followed up. Therefore, it is necessary to immediately follow up and make actions on the cases decided by the KPPU on the involvement of procurement officials. Actions needed are in the form of joint investigation with other law enforcement institutions including adopting procedural law.

\section{References}

[1] Badan Perencanaan dan Pembangunan Nasional (2017). Perkembangan Ekonomi Indonesia dan Dunia Triwulan I Tahun 2017. Retreived from https://www.bappenas.go.id/id/berita-dansiaran-pers/perkembangan-ekonomi-indonesia-dan-duniatriwulan-i-tahun-2017/

[2] Trading Economics (2017). Indonesian GDP. Retrieved from https://tradingeconomics.com/indonesia/gdp.

[3] World Bank (2017) Indonesia Overview. Retrieved from http://www.worldbank.org/en/country/indonesia/overview.

[4] World Bank, (2017) Perkembangan Triwulanan Perekonomian Indonesia Juni 2017: Naik Peringkat. Retrieved from http://www.worldbank.org/in/country/indonesia/publication/ind onesia-economic-quarterly-june-2017

[5] Trading Economics, (2017) Indonesian Corruption Index. Retrieved https://tradingeconomics.com/indonesia/corruption-index.

[6] Republic of Indonesia, Peraturan Pemerintah No. 54 Tahun 2010 tentang Pengadaan Barang/Jasa Pemerintah.

[7] Attström, Karin and Ismail, Rusman. (November 2010). Indonesia Strengthening Public Procurement Program. Ausaid.

[8] Yin, Robert. K, Application of Case Study Research, New Delhi, Sage Publications International Educational and Professional Publisher Newbury Park, 1993.

[9] Komisi Pemberantasan Korupsi (2016). Kajian Pencegahan Korupsi Pada Pengadaan Barang dan Jasa Pemerintah. Jakarta. 
[10] Komisi Pengawas Persaingan Usaha (2012). Laporan Kinerja KPPU Tahun 2012: Periode Penguatan Perekonomian Melalui Persaingan Usaha. Jakarta.

[11] Badan Pemeriksa Keuangan Republik Indonesia (2014). Ikhtisar Hasil Pemeriksaan Semester II Tahun 2014. Jakarta.

[12] Rahardjo, Supratikno (2011). Peradaban Jawa : Dari Mataram Kuno sampai Majapahit Akhir, Komunitas Bambu, Jakarta, Indonesia.

[13] Raffles, Thomas Stamford (2004). The History of Java, Penerbit Narasi, Yogyakarta.

[14] Simamora, T., Korupsi Secara Etimologi. 2017.

[15] Klitgaard, R. (1988). Controlling corruption. University of California Press. California.

[16] Badudu, J.S. \& Zain, S.M., (1994). Kamus Umum Bahasa Indonesia, Pustaka Sinar Harapan, Jakarta.

[17] Hindia Belanda (1918) Wetboek van StrafrechtvoorNederlandsh-Indie.

[18] Yahya, Iip D. (2004). Mengadili Menteri, Memeriksa Perwira: Jaksa Agung Soeprapto dan Penegak Hukum di Indonesia Periode 1950-1959, Gramedia Pustaka Utama, Jakarta.

[19] Prodjohamidjojo (2001). Martiman, Penerapan Pembuktian Terbalik dalam Delik Korupsi (UU No. 31 Tahun 1999). Penerbit Mandar Maju, Bandung.

[20] Republic of Indonesia, Law No. 24/Prp/Tahun 1960 tentang Pengusutan, Penuntutan, dan Pemeriksaan Tindak Pidana Korupsi.

[21] Republic of Indonesia, Law No. 3 Year 1971 tentang Pemberantasan Tindak Pidana Korupsi.

[22] Republic of Indonesia, Law No. 11 Year 1980 tentang Penyuapan

[23] Republic of Indonesia, Law No. 5 Year 1999 on Prohibitions of Antimonopoly and Unfair Business Practices.

[24] Republic of Indonesia, Law No. 8 Year 1999 tentang Perlindungan Konsumen

[25] Republic of Indonesia, Law No. 28 Year 1999 tentang Penyelenggaraan Negera yang Bersih dan Bebas dari Korupsi, Kolusi, dan Nepotisme

[26] Republic of Indonesia, Law No. 31 Year 1999 tentang Pemberantasan Tindak Pidana Korupsi.

[27] Republic of Indonesia, Law No. 20 Year 2001 tentang Perubahan terhadap Law No. 31 Year 1999 tentang Pemberantasan Tindak Pidana Korupsi.

[28] Republic of Indonesia, Law No. 20 Year 2002 tentang Komisi Pemberantasan Tindak Pidana Korupsi

[29] Republic of Indonesia, Law No. 46 Year 2009 tentang Pengadilan Tindak Pidana Korupsi

[30] Republic of Indonesia, Law No. 15 Year 2002 tentang Tindak Pidana Pencucian Uang
[31] Republic of Indonesia, Law No. 24 Year 2003 tentang Perubahan atas Undang-Undang No 15 Tahun 2002 tentang Tindak Pidana Pencucian Uang

[32] Republic of Indonesia, Law No. 1 Tahun 2006 tentang Bantuan Timbal Balik Masalah Pidana.

[33] Republic of Indonesia, Law No. 7 Tahun 2006 tentang Pengesahan Konvensi Perserikatan Bangsa-Bangsa Anti Korupsi Tahun 2003

[34] Republic of Indonesia, Law No. 13 Tahun 2006 tentang Pelindungan Saksi dan Korban

[35] Republic of Indonesia, Law No. 8 Tahun 2010 tentang Pencegahan dan Pemberantasan Tindak Pidana Pencucian Uang

[36] Indonesian Corrruption Watch (2016). Tren Penindakan Korupsi 2016: Gagalnya Reformasi Birokrasi Dan Berkembangnya Fenomena Local Elite Capture. Retrieved from http://www.antikorupsi.org/id/content/tren-penindakan-korupsi2016-gagalnya-reformasi-birokrasi-dan-berkembangnyafenomena-local.

[37] World Economic Forum (2016). The Global Competitiveness Report 2016-2017. Retrieved from http://www3.weforum.org/docs/GCR20162017/05FullReport/TheGlobalCompetitivenessReport 20162017_FINAL.pdf

[38] Republic of Indonesia, 1950 Provisional Constitution.

[39] Republic of Indonesia, 1945 Constitution.

[40] Komisi Pengawas Persaingan Usaha (2012), KPPU Decision Putusan No. 01/KPPU-L/2000.

[41] Komisi Pengawas Persaingan Usaha (2012), KPPU Decision Putusan No. 07/KPPU-L-I/2001.

[42] Komisi Pengawas Persaingan Usaha (2012), KPPU Decision Putusan No. 03/KPPU-I/2002.

[43] Komisi Pengawas Persaingan Usaha (2012), KPPU Decision Putusan No. 7/KPPU-L/2004.

[44] Komisi Pengawas Persaingan Usaha (2012), KPPU Decision Putusan No. 08/KPPU-L/2004.

[45] Komisi Pengawas Persaingan Usaha (2012), KPPU Decision Putusan No. 3/KPPU-L/2012.

[46] OECD (2010). Policy Roundtables: Collution and Corruption in Public Procurement. Retrieved form http://www3.weforum.org/docs/GCR20162017/05FullReport/TheGlobalCompetitivenessReport 20162017_FINAL.pdf

[47] Trading Economics, (2017) Indonesian Competitiveness Index. Retrieved from https://tradingeconomics.com/indonesia/competitiveness-index

[48] Trading Economics, (2017) Indonesian Corruption Rank. Retrieved from https://tradingeconomics.com/indonesia/corruption-rank 